DOI:

Роман Петренко, аспірант кафедри загальної педагогіки та дошкільної освіти Дрогобииького державного педагогічного університету імені Івана Франка

\title{
ОСНОВНІ ПІДХОДИ ДО РЕАЛІЗАЦІЇ ПРАВА ЗАСУДЖЕНИХ НА ОСВІТУ В ПЕНІТЕНЦІАРНИХ ЗАКЛАДАХ УКРАЇНИ ДРУГОЇ ПОЛОВИНИ ХХ СТ.
}

У статті аналізуються основні підходи до реалізачії права засуджених на освіту в пенітенціарних закладах України упродовж другої половини ХХ ст. Виокремлено періоди, протягом яких змінювалась законодавча база, система освітніх закладів для засуджених та форми ї̈ отримання: перший-50-60-ті рр. $X X \mathrm{~cm}$. (розробка нормативно-законодавчої бази щзодо здобуття засудженими різних рівнів освіти; обов'язковість загальноосвітньої підготовки); другий - 70-80-ті рр. ХХ ст. (створення системи професійнотехнічної освіти; розробка різних форм організачії професійно-технічного навчання); третій - 90-ті рр. ХХ сm. (занепад та руйнація загальноосвітньої та професійно-технічної освіти засуджених; закриття вечірніх шкіл і професійно-технічних училищ у пенітенціарних установах); четвертий-2000-ні рр. ХХ ст. (відновлення мережі закладів загальної середньої освіти при всіх виправних та виховних колоніях, а також слідчих ізоляторах; відновлення мережі професійно-технічних закладів освіти при установах виконання покарань). Обтрунтовано важливість здобуття освіти засудженими в пенітенціарних закладах як необхідної умови отримання якісних знань, умінь, навичок та професійної кваліфікації, що в подальшому сприятиме їх особистісному розвитку і ресоиіалізації в суспільстві.

Ключові слова: виправно-трудове законодавство; пенітениіарні заклади; професійно-технічна освіта; загальноосвітня підготовка; засуджені; ресочіалізація.

Jim. 8.

Roman Petrenko, Postgraduate Student of the General and Preschool Education Department Drohobych Ivan Franko State Pedagogical University

\section{THE MAIN APPROACHES TO THE IMPLEMENTATION OF CONCICTED RIGHTS FOR EDUCATION IN PENITENTIAL INSTITUTIONS OF UKRAINE IN THE SECOND HALF OFTHE XX CENTURY}

The main approaches to the realization of the right of convicts to education in penitentiary institutions of Ukraine during the second half of the twentieth century are analyzed in the article. It is stated that at the beginning of this period (in the 50-60s of the twentieth century) the regulatory framework was developed for convicts to obtain different levels of education, ranging from primary to vocational; general education is becoming a mandatory element of the system of means of correction and re-education of convicts. It is emphasized that the 70-80s of the twentieth century, characterized by the creation of a system of vocational education for convicts; development of various forms of organization of vocational training of convicts in penitentiary institutions: individual, brigade, course training, training in vocational school without separation from production, training of convicts in schools of excellence and in master classes. It is determined that the $90 \mathrm{~s}$ of the twentieth century were a period of decline and destruction of general and vocational education of convicts; the era of mass closure of evening schools and vocational schools in penitentiary institutions. It is proved that the restoration of the network of general educational institutions at all correctional and educational colonies, as well as pre-trial detention centers began in the 2000s; restoration of the network of vocational schools at penitentiary institutions. The importance of obtaining education by convicts in penitentiary institutions as a necessary condition for obtaining quality knowledge, skills, abilities and professional qualifications, which will further contribute to their personal development and resocialization in society, is substantiated.

Keywords: correctional and labor legislation; penitentiary institutions; vocational schools; evening schools; vocational education; general education; convicts; resocialization.

П остановка проблеми. Освіта як основа отримання людиною систематизованих знань і формування ціннісних орієнтирів $\epsilon$ необхідною умовою їі особистісного становлення. Право на освіту в нашій державі має кожен громадянин, що гарантовано на законодавчому рівні Конституцією України. Так, у ст. 53 задекларовано доступність та безоплатність дошкільної, повної загальної середньої, професійнотехнічної, вищої освіти в державних і комунальних навчальних закладах. А згідно зі ст. 24, право на освіту гарантується кожній людині на принципах рівності [5]. Власне про це йдеться і у низці відповідних міжнародних документів: Загальній декларації прав людини (ст. 26), Міжнародному пакті про економічні, соціальні та культурні права 


\section{ОСНОВНІПДХОДИ ДО РЕАЛІЗАЦІЇ ПРАВА ЗАСУДЖЕНИХ НА ОСВІТУ \\ В ПЕНТТЕНЦАРНИХ ЗАКЛАДАХУКРАЇНИ ДРУГОЇ ПОЛОВИНИ ХХСТ.}

(ст. 13) та ін. [6]. Отож, правом на отримання освіти володіють і засуджені, що відбувають покарання в пенітенціарних закладах. Адже їм, як і будь-яким іншим громадянам України, держава має забезпечити належні умови для отримання якісних знань, умінь, навичок та професійної кваліфікації, що в подальшому сприятиме їх особистісному розвитку та ресоціалізації в суспільстві.

Аналіз останніх досліджень і публікацій. Питання доступності освіти розроблялися багатьма науковцями. Його досліджували представники різних галузей: правники, філософи, психологи та педагоги. Філософські аспекти означеного поняття з'ясовували Б. Гершунський [2], Т. Кучера, Л. Насонова, В. Дейнека та ін.; правові-В. Боняк[1], А. Васильєва, О. Домаранський, В. Жирнов, В. Журавльов, Н. Шукліната ін.; психологічні - С. Панченко та ін.; педагогічні В. Алексєєв, І. Апрелєва та ін. Їхні розвідки висвітлювали реалізацію принципу доступності освіти для різних категорій громадян, утому числі і засуджених.

У філософії освіти розглядуване поняття тлумачиться у контексті панування у суспільстві гуманістичних цінностей, а сама освіта охоплює три взаємопов'язані блоки: 1) як державна цінність; 2) як суспільна цінність; 3) як особистісна цінність [2].

Правознавці акцентують на нормативноправовій складовій освіти. Зокрема, В. Боняк, здійснивши системний аналіз норм внутрішнього законодавства, резюмує, що “право на освіту це реально існуюча та гарантована державою можливість кожного громадянина користуватися усіма відображеними у законі благами у сфері освіти” [1, 107]. Дослідниця Н. Шукліна право особи на освіту вважає “ядром культурних прав та свобод людини і громадянина”, а освіту “однією з найважливіших умов усебічного розвитку кожного” $[8,79]$.

Педагоги при дослідженні аналізованої проблеми в основному зосереджувалися на іiі історично-організаційному аспекті (В. Алексєєв та ін.), на характеристиці особливостей здобуття освіти засудженими у різних типах виправних закладів (Н. Калашник, Н. Максимова, О. Янчук). Науковці зокрема зазначають, що виникнення і становлення освіти осіб, позбавлених волі, - це триваючий у часі соціально-педагогічний процес. Різні його етапи в окремі історичні періоди дають змогу вважати освіту дієвим засобом виправлення і ресоціалізації засуджених [3, 83].

3 огляду на це ретроспективний аналіз розвитку та реалізації освіти засуджених упродовж виконання покарання має не тільки теоретичне, пізнавальне, а й важливе практичне значення, оскільки уможливлює творче використання накопиченого досвіду, уникнення певних помилок, що мали місце в минулому. Тому метою нашої наукової розвідки є висвітлення основних підходів до реалізації права засуджених на освіту в пенітенціарних закладах України впродовж другої половини XX ст.

Виклад основного матеріалу. У 1954-1961 pp. Радою Міністрів СРСР було прийнято низку постанов про поліпшення діяльності виправнотрудових установ, у яких декларувався розвиток загальноосвітнього навчання засуджених до позбавлення волі. У цей період були створені перші навчально-консультаційні пункти, організовувалося заочне навчання засуджених. Найпоширенішими у цей час у місцях позбавлення волі були вечірні восьмирічні і середні школи, що відкривалися виконкомами місцевих Рад депутатів трудящих за спільним поданням органів народної освіти і внутрішніх справ. Такі освітні заклади мали перевагу над заочними школами, тому що учні в них постійно перебували під опікою учителів, які, окрім навчальної, проводили з ними різнопланову позанавчальну роботу.

Окрім восьмирічних і середніх шкіл, згідно 3 Положенням про загальноосвітні школи виправнотрудових установ Ради Міністрів СРСР, затвердженим Міністерством освіти СРСР і погодженим із Міністерством внутрішніх справ СРСР у 1958 р., у ВТУ (виправно-трудових установах) за потреби організовувалися і початкові школи для тих, хто не мав початкової освіти.

За відсутності умов для дистанційного або заочного навчання, особливо у старших класах, засуджені могли придбати підручники і займатися самостійно, здаючи екзамени екстерном. Окрім того, практикувалося навчання малограмотних, неписьменних і засуджених похилого віку шляхом організації індивідуально-групових занять 3 особами, які мали достатній рівень освіти, тобто т. зв. взаємонавчання. Цікавим $\epsilon$ і той факт, що для учнів ВТУ існувала певна система пільг: у період навчання вони не підлягали переводу в інші підрозділи, звільнялися від роботи на час складання екзаменів (без збереження заробітної плати), у години навчання у школі не використовувалися на господарських роботах, вчасно обслуговувалися в їдальні, лазні, магазині. Це, на нашу думку, певною мірою сприяло мотивації засуджених до отримання освіти.

Згідно з Положенням про виправно-трудові колонії і тюрми, прийнятим Радою Міністрів СРСР у 1961 р., для засуджених у віці до 50 років 


\section{ОСНОВНІ ПДХОДИ ДО РЕАЛІЗАЦІЇ ПРАВА ЗАСУДЖЕНИХ НА ОСВІТУ}

\section{В ПЕНІТЕНЦАРНИХ ЗАКЛАДАХ УКРАЇНИ ДРУГОЇ ПОЛОВИНИ ХХ СТ.}

було обов'язковим отримання восьмирічної освіти. Детально питання здійснення загальноосвітньої підготовки регулювалося Інструкцією про застосування Положення про вечірню школу СРСР у загальноосвітніх вечірніх школах виправно-трудових установ.

Зазначимо, що мережа професійно-технічних училищ та їхніх філій значно розширилася після прийняття Положення про професійно-технічне навчання ув'язнених у 1965 р. Відповідно до нього, у період навчальних занять учні не залучалися до виконання понаднормових та інших робіт, їх мали вчасно обслуговувати в їдальні, лазні, магазині, щоб вони могли прибути на навчання у встановлений час. У Положенні визначалися і заходи впливу на ув'язнених, які порушували навчальну дисципліну. До прикладу, учні, які систематично пропускали заняття без поважних причин, відраховувалися з професійно-технічного училища після застосування всіх засобів і заходів адміністративного впливу за узгодженням 3 адміністрацією виправно-трудової установи.

Окрім того, в аналізований період значно розширилася мережа середніх шкіл і навчальноконсультаційних пунктів для засуджених. Згідно з Основами виправно-трудового законодавства Союзу РСР і союзних республік, прийнятими у 1969 р., кожному засудженому гарантувалося право на загальну освіту. Щобільше, у ст. 7 зазначених Основ ішлося про обов'язковий восьмирічний “всеобуч” засуджених, який було визнано одним із важливих засобів їх виправлення й перевиховання. "Всеобучу” підлягали всі особи, які не мали закінченої восьмирічної освіти. Одночасно активно пропагувалося максимальне залучення всіх засуджених, які бажають навчатися, до старших класів.

Основи виправно-трудового законодавства, прийняті у 1969 р., визнали професійно-технічне навчання засуджених одним з основних засобів їхнього виправлення і перевиховання. Відповідно до ст. 31 Основ, кожен засуджений, відбуваючи покарання, мав право отримати професійнотехнічну освіту. У ст. 30 Основ законодавства про народну освіту 1973 р. наголошувалося, що професійно-технічні навчальні заклади є основною школою професійно-технічної освіти молоді. Це законодавче положення безпосередньо сприяло удосконаленню професійного навчання засуджених у місцях позбавлення волі. Аналіз спеціальної літератури показав, що у 1971-1977 pp. підготовка фахівців у професійно-технічних училищах та їхніх філіях зросла удвічі. До цього часу переважна більшість вітчизняних виправнотрудових установ мала у своєму розпорядженні відповідно обладнані професійно-технічні училища $[4,7]$.

Міністерством внутрішніх справ СРСР були розроблені конкретні заходи для подальшого удосконалення професійно-технічного навчання засуджених, а також визначені перспективні завдання, одним з яких було завершення впродовж 1979-1982 рр. створення профтехучилищ та їхніх філій у всіх виправно-трудових установах i лікувально-трудових профілакторіях. Професійна підготовка осіб, позбавлених волі, організовувалася згідно 3 Основами виправно-трудового законодавства, виправно-трудовими кодексами та відповідними документами Державного комітету Ради Міністрів СРСР з професійно-технічної освіти без відриву від виробництва.

Керівництво професійно-технічним навчанням засуджених, а також планування, фінансування і контроль за станом цієї роботи здійснювали Головне управління виправно-трудових установ і Головне управління лісних виправно-трудових установ Міністерства внутрішніх справ. Головними принципами організації тодішнього професійно-технічного навчання засуджених були основні принципи народної освіти, трансформовані з урахуванням специфіки здійснення навчання у місцях позбавлення волі.

Правильний вибір кожним засудженим професії $\epsilon$ важливим чинником у профілактиці рецидивної злочинності і забезпеченні виробництва кваліфікованими фахівцями. Тому при визначенні набору спеціальностей профтехучилищ ураховувалися потреби тих чи тих регіонів країни у кваліфікованій робочій силі; перевага при цьому надавалася широкопрофільним професіям, що забезпечують швидку перекваліфікацію після звільнення.

До професійно-технічного училища передусім зараховували засуджених, які не мали спеціальності. Але, як показала практика, для деяких із них навчання було тягарем, тому майстри виробничого навчання й інженернотехнічні працівники мали переконувати засуджених у необхідності набуття і розширення знань за фахом, на конкретних прикладах демонструвати, що без професійних знань і навичок не можна забезпечити своє життя на волі. Засудженим, які не мали загальної освіти, рекомендували спочатку закінчити школу, а потім вступати до училища, оскільки середня освіта була і є необхідною базою до опанування професійно-технічними спеціальностями.

Упродовж досліджуваного нами періоду до норм виправно-трудового права неодноразово вносилися зміни, у тому числі й ті, що регулювали 


\section{ОСНОВНІ ПІДХОДИ ДО РЕАЛІЗАЦІЇ ПРАВА ЗАСУДЖЕНИХ НА ОСВІТУ В ПЕНІТЕНЦАРНИХ ЗАКЛАДАХУКРАЇНИ ДРУГОЇ ПОЛОВИНИ ХХСТ.}

загальноосвітнє навчання у виправно-трудових установах. Так, у 1980 р. законодавчо було закріплено обов'язок отримання загальної середньої освіти засудженими у віці до 30 років, а у 1985 р. - у віці до 40 років. У 1984 р. були прийняті Основні напрями реформи загальноосвітньої і професійної школи, що висунули перед загальноосвітнім навчанням засуджених нові завдання [7, 24].

Вивчення тогочасних статистичних відомостей дає підстави стверджувати, що до початку реформування кримінально-виконавчої систем України (1993) кількість засуджених, які мають початкову, неповну середню освіту, зменшилася, натомість зросла кількість осіб із загальносередньою, середньо-спеціальною, незакінченою вищою й вищою освітою. Відповідно зменшилася кількість осіб, які потребували загальноосвітнього навчання. Окрім того, погіршення соціальноекономічних умов у державі викликало певні труднощі у фінансуванні пенітенціарних закладів. Усе це спричинило зменшення кількості загальноосвітніх шкіл при виправних установах.

Як відомо, після розпаду Радянського Союзу через відсутність належного фінансування у 1992 р. професійно-технічні навчальні училища у виправних установах були закриті. При цьому кваліфіковані працівники були звільнені, а навчальна матеріально-технічна база професійнотехнічних училищ - ліквідована. Вдалося зберегти лише ті, що діяли при 11 виховних колоніях, у яких утримувалися неповнолітні засуджені.

Отже, у 1991-1993 рр. у результаті формальнобюрократичного виконання Закону України "Про освіту” фактично була зруйнована система вечірніх шкіл і професійно-технічних училищ у виправних колоніях.

У 2004 р. $з$ утворенням Державного департаменту України 3 питань виконання покарань як центрального органу виконавчої влади зі спеціальним статусом почалася робота 3 відновлення в пенітенціарних установах шкіл та професійно-технічних училищ. У 2004-2007 рр. були створені навчальні центри при 82 виправних колоніях, де щорічно здобували професійнотехнічну освіту та підвищували свою кваліфікацію понад 12 тисяч засуджених за 65 робітничими професіями. Отож, можемо стверджувати, що наприкінці XX ст., а саме у 2000-х рр., загальноосвітньому та професійно-технічному навчанню засуджених в Україні почала приділятися підвищена увага, що сприяло відновленню й розвитку загальноосвітніх та професійно-технічних установ для засуджених

Висновки. Доходимо висновку, що упродовж досліджуваного нами періоду (др. пол. ХХ ст.) змінювалися підходи до реалізації права засуджених на освіту в пенітенціарних закладах України, що було зумовлене великою мірою державною політикою в цій царині. Так, на початку означеного періоду (у 50-60-ті рр. ХХ ст.) розроблялася нормативно-законодавча база щодо здобуття засудженими різних рівнів освіти, починаючи від початкової до професійнотехнічної; загальноосвітня підготовка стає обов'язковим елементом системи засобів виправлення й перевиховання засуджених. 70-80-ті рр. XX ст. характеризуються створенням системи професійно-технічної освіти для засуджених; розробкою різних форм організації професійнотехнічного навчання засуджених у пенітенціарних закладах: індивідуальною, бригадною, курсового навчання, навчання у професійно-технічному училищі без відриву від виробництва, навчання засуджених у школах передового досвіду і в класах майстрів. 90-ті pp. XX ст. - це період занепаду та руйнації загальноосвітньої та професійно-технічної освіти засуджених; доба масового закриття вечірніх шкіл і професійнотехнічних училищ у пенітенціарних установах. Після 2000-х рр. ХХ ст. розпочалося відновлення мережі закладів загальної середньої освіти при всіх виправних та виховних колоніях, а також слідчих ізоляторах; відновлення мережі професійнотехнічних закладів освіти при установах виконання покарань; надання прав на освіту засуджених особливого значення для майбутньої їх ресоціалізації. Подальших розвідок потребує розгляд питання доступу до освіти засуджених у сучасних пенітенціарних закладах України.

\section{ЛІТЕРАТУРА}

1. Боняк В. О. Конституційне право людини і громадянина на освіту в Україні : моногр. Дніпропетровськ : Дніпроп. держ. ун-т. внутр. справ ; Ліра ЛТД, 2008. 180 с.

2. Гершунский Б. В. Философия образования. Москва : Флинта, 1998. 432 с.

3. Калашник Н. Г., Максимова Н.Ю., Янчук О.Б. Соціально-психологічні аспекти оптимізації навчально-виховного процесу в закладах освіти при виховних колоніях для неповнолітніх засуджених : метод. рек. Київ, 2009. С. 82-83.

4. Коновалов Б. И. Производственную базу при ИТУ - на службу исправления осужденных. Исправительно-трудовые учреждения. Информ. бюллетень. Москва, 1978. № 5. С. 6-9.

5. Конституція України : станом на 01 січ. 2006 р. Міністерство юстиції України : офіц. вид. Київ, 2006. 123 c. 
6. Міжнародний пакт про економічні, соціальні і культурні права. Прийнято 16 грудня 1966 року Генеральною Асамблеєю ОOH. URL: http:// zakon.rada.gov.ua/cgi-bin/laws/ main.cgi?nreg=995 042

7. Наташев А.Е. Советское исправительнотрудовое законодательство (основные вопросы теории и практики). Москва : Изд. ВНИИ МВД СССР, 1975. 168 с.

8. Шукліна Н. Г. Конституційне право : навч. посібник. Київ : Юрінком Інтер, 2008. 632 с.

\section{REFERENCES}

1. Boniak, V. O. (2008). Konstytutsiine pravo liudyny i hromadianyna na osvitu $\mathrm{v}$ Ukraini [The constitutional right of man and citizen to education in Ukraine]. Monohraf. Dnipropetrovsk, 180 p. [in Ukrainian].

2. Hershunskyi, B. V. (1998). Fylosofyia obrazovanyia [Philosophy of education]. Moscov, $432 \mathrm{p}$. [in Russian].

3. Kalashnyk, N. H., Maksymova, N.Iu. \& Yanchuk, O.B. (2009). Sotsialno-psykholohichni aspekty optymizatsii navchalno-vykhovnoho protsesu v zakladakh osvity pry vykhovnykh koloniiakh dlia nepovnolitnikh zasudzhenykh [Socio-psychological aspects of optimization of the educational process in educational institutions at educational colonies for juvenile convicts]. Kyiv, pp. 82-83. [in Ukrainian].

4. Konovalov, B. I. (1978). Proizvodstvennuyu bazu pri ITU - na sluzhbu ispravleniya osuzhdennykh [The production base at the ITU - for the correction of convicts]. Inform. newsletter. Moscov, no. 5. pp. 6 9. [in Russian].

5. Konstytutsiia Ukrainy : stanom na 01 sich. (2006). Ministerstvo yustytsii Ukrainy [Constitution of Ukraine: as of January 1. 2006]. Kyiv, 123 p. [in Ukrainian].

6. Mizhnarodnyi pakt pro ekonomichni, sotsialni i kulturni prava. Pryiniato 16 hrudnia 1966 roku Heneralnoiu Asambleieiu OON [International Covenant on Economic, Social and Cultural Rights]. Adopted on December 16, 1966 by the UN General Assembly. Available at:http://zakon.rada.gov.ua/cgibin/laws/main.cgi?nreg=995 042[in Ukrainian].

7. Natashev, A.Ye. (1975). Sovetskoe ispravitelnotrudovoe zakonodatelstvo (osnovnye voprosy teorii i praktiki) [Soviet correctional labor legislation (basic issues of theory and practice)]. Moscova, 168 p. [in Russian].

8. Shuklina, N. H. (2008). Konstytutsiine pravo [A constitutional right]. Studying Manual. Kyiv, 632 p. [in Ukrainian].

Стаття надійшла до редакції 11.08.2021

\title{
OS808NC2058080
}

\author{
"Велика безодня сама людина, волосинки ї̈ легше полічити, ніж почуття та \\ порухи ї̈ серия”.
}

“Не виходь у світ, а повертайся до самого себе: всередині людини знаходиться правда".

“Хто шукає - не помиляється".

Аврелій Августин Блаженний християнський теолог і церковний діяч

"Нехай наші очі бачать в людях найқраще, серия вибачають найгірше, а душі не втрачають віри".

Ельчин Саббарлі

сучасний азейбаржанський письменник

“Боже, дай мені розум і душевний споқій, щоб змиритися з тим, що я не можу змінити; сиху, аби змінити те, що можу і мудрість відрізнити одне від одного".

Климентій Шептищький

Блаженний священномученик

\section{G58080}

